Article

\title{
Preparation of Stable Cross-Linked Enzyme Aggregates (CLEAs) of a Ureibacillus thermosphaericus Esterase for Application in Malathion Removal from Wastewater
}

\author{
Yuliya V. Samoylova ${ }^{1}$, Ksenia N. Sorokina ${ }^{1,2, *}$, Alexander V. Piligaev ${ }^{1}$ and \\ Valentin N. Parmon 1,2 \\ 1 Boreskov Institute of Catalysis (BIC), Lavrentieva ave. 5, 630090 Novosibirsk, Russia; \\ samoylova.jv@catalysis.ru (Y.V.S.); piligaev@catalysis.ru (A.V.P.); parmon@catalysis.ru (V.N.P.) \\ 2 Novosibirsk State University (NSU), Pirogova str. 2, 630090 Novosibirsk, Russia \\ * Correspondence: sorokina@catalysis.ru; Tel.: +7-383-326-95-86
}

Received: 26 March 2018; Accepted: 8 April 2018; Published: 11 April 2018

\begin{abstract}
In this study, the active and stable cross-linked enzyme aggregates (CLEAs) of the thermostable esterase estUT1 of the bacterium Ureibacillus thermosphaericus were prepared for application in malathion removal from municipal wastewater. Co-expression of esterase with an E. coli chaperone team (KJE, ClpB, and ELS) increased the activity of the soluble enzyme fraction up to $200.7 \pm 15.5 \mathrm{U} \mathrm{mg}^{-1}$. Response surface methodology (RSM) was used to optimize the preparation of the CLEA-estUT1 biocatalyst to maximize its activity and minimize enzyme loss. CLEA-estUT1 with the highest activity of $29.4 \pm 0.5 \mathrm{U} \mathrm{mg}^{-1}$ ( $90.6 \pm 2.7 \%$ of the recovered activity) was prepared with $65.1 \%(w / v)$ ammonium sulfate, $120.6 \mathrm{mM}$ glutaraldehyde, and $0.2 \mathrm{mM}$ bovine serum albumin at $5.1 \mathrm{~h}$ of cross-linking. The biocatalyst has maximal activity at $80^{\circ} \mathrm{C}$ and $\mathrm{pH}$ 8.0. Analysis of the properties of CLEA-estUT1 and free enzyme at $50-80^{\circ} \mathrm{C}$ and $\mathrm{pH} 5.0-10.0$ showed higher stability of the biocatalyst. CLEA-estUT1 showed marked tolerance against a number of chemicals and high operational stability and activity in the reaction of malathion hydrolysis in wastewater (up to $99.5 \pm 1.4 \%$ ). After 25 cycles of malathion hydrolysis at $37^{\circ} \mathrm{C}$, it retained $55.2 \pm 1.1 \%$ of the initial activity. The high stability and reusability of CLEA-estUT1 make it applicable for the degradation of insecticides.
\end{abstract}

Keywords: molecular chaperones; esterase; Ureibacillus thermosphaericus; cross-linked enzyme aggregates; response surface methodology; malathion hydrolysis

\section{Introduction}

Malathion (S-(1,2-dicarbethoxyethyl)-O,O-dimethyldithiophosphate) is a broad-spectrum insecticide which is widely used due to its efficiency for pest and insect control and low price. However, malathion and its derivates are highly toxic for living organisms, including humans. Malathion mainly targets the central nervous and immune systems and causes various symptoms including dizziness, nausea, and attention disorder [1]. Therefore, it is important to prevent the pollution of air and soil and especially water with this insecticide [2,3]. There are several approaches to degrading malathion in wastewater, including chemical oxidation [3], ultraviolet irradiation [4], nanofiltration [3], and biological treatment (with bacteria [5], fungi [6], and algae [7]). Currently, biological treatment is considered as a preferred method for malathion removal from aqueous solutions, since it is inexpensive, less time-consuming, and in most cases, provides complete degradation of this insecticide. A wide range of bacteria, including Bacillus licheniformis [8], 
Pseudomonas putida, Pseudomonas sp. [9], Rhodoccocus rhodochrous, and Sphingomonas sp. [5], have been successfully applied in malathion biodegradation due to their ability to produce hydrolytic enzymes (hydrolases and carboxylesterases). Application of purified microbial hydrolytic enzymes is an alternative way to degrade malathion as they have higher activity and specificity as compared to the microbial strains $[10,11]$. Their immobilization allows their activity and stability to be increased and promotes their separation from the reaction medium, along with repeated use [12-14]. Currently, the hydrolytic immobilized enzymes are not applied for malathion removal from municipal wastewater, but Adhikari et al. [15] applied immobilized cells of Bacillus sp. S14 for its hydrolysis in aqueous solutions.

The widespread application of hydrolytic enzymes (lipases and esterases) in industry and for the biodegradation of insecticides is still limited by their high production costs. One of the problems is the low protein expression in common host systems. This may be the result of the toxicity of the expressed proteins [16], presence of disulfide bonds [17], or inactivation of the protein and formation of inclusion bodies after intracellular aggregation of proteins $[18,19]$. Expression of molecular chaperones and chaperonins with enzymes can decrease the formation of protein aggregates. It was shown that the co-expression of the E. coli DnaK and GroEL chaperone team proved to be most effective for increasing the expression of lipase from Psychrobacter sp. in a soluble form, as compared to expression with each chaperone alone [20]. Application of this approach allows the yield of protein to be increased, thereby reducing the cost of its production.

In addition to high protein activity, the stability in a wide range of $\mathrm{pH}$ and temperature, along with superior tolerance to solvents and chemicals [21], are required for the successful application of enzymes in various processes, including malathion removal from municipal wastewater. Immobilization prolongs protein operation and can be performed by physical adsorption, entrapment, covalent bonding, and cross-linking (carrier free) [22]. Among these methods, the application of cross-linked enzyme aggregates (CLEAs) is a prospective immobilization approach that combines all steps of preparation (purification, precipitation, and immobilization) in one, making the process simple, time-saving, and low-cost. CLEAs biocatalysts have high activity and stability over a wide range of $\mathrm{pH}(4.0-11.0)$ [23], temperature $\left(10-90^{\circ} \mathrm{C}\right)[24,25]$, and a high tolerance to chemical reagents including phenylmethylsulfonyl fluoride (PMSF), sodium dodecyl sulfate (SDS), ethanol, and phenol [26]. Such biocatalysts were previously successfully applied for the production of biodiesel $[27,28]$ and chemicals [29], but not for insecticide degradation.

In this study, we report the preparation of a highly active CLEAs biocatalyst from the novel thermostable esterase estUT1 of the bacterium Ureibacillus thermosphaericus for application in malathion removal from real wastewater. Co-expression of the E. coli chaperone team of KJE, ClpB, and ELS with the esterase led to an increase in the production of soluble and active enzyme. Optimization of the biocatalyst preparation was performed with response surface methodology (RSM) using face-centered central composite design (FCCCD) for the following parameters: cross-linking time and concentrations of precipitating reagent, glutaraldehyde, and chemical additives. The biocatalyst was stable in a wide range of $\mathrm{pH}$ and temperature and in the presence of various chemicals, and was further tested in the reaction of malathion hydrolysis in municipal wastewater. Therefore, this approach allowed the yield of soluble estUT1 in E. coli to be increased and enzyme loss to be reduced during the preparation of a highly active and stable biocatalyst for application in the degradation of organophosphorus insecticide during wastewater treatment.

\section{Results and Discussion}

\subsection{Chaperone Co-Expression with estUT1}

Recently, we have cloned and studied properties of the new thermostable esterase estUT1 from the bacterium $U$. thermosphaericus [30]. EstUT1 is stable at pH 5.0-9.0, at temperature $50-70{ }^{\circ} \mathrm{C}$, and is tolerant to various chemicals and organic solvents, which makes it promising for application 
as a catalyst in wastewater treatment for malathion removal. The esterase estUT1 is expressed in E. coli BL21(DE3) as inclusion bodies that need to be further refolded in vitro [30]. In this respect, the co-expression of a combination of molecular chaperones and chaperonins with the recombinant proteins is the one of the strategies to solve this problem. The DnaK system (DnaK with its co-chaperones DnaJ and GrpE; KJE) prevents formation of the inclusion bodies by reducing aggregation and stimulating the proteolysis of misfolded proteins [31]. The bi-chaperone system comprised by $\mathrm{KJE}$ and $\mathrm{ClpB}$ promotes solubilization and disaggregation of proteins [32,33]. The GroEL system (GroEL with its co-chaperonin GroES; ELS) promotes protein transit between the soluble and insoluble protein fractions [34]. Therefore, to study the influence of chaperones on the expression of estUT1, a combination of $\mathrm{KJE}, \mathrm{ClpB}$, and ELS chaperones was used as one of the most effective folding systems. Previously, it was shown that a chaperone team (KJE, ClpB, and ELS) improves the yield of soluble fraction of proteins expressed in E. coli by 2.5-3.5 times [35].

In this study, the estUT1 gene was expressed in E. coli BL21(DE3) as a His-tagged fusion protein. The esterase estUT1 alone was produced as inclusion bodies in the insoluble fraction (Figure 1, line 2) [30]. Its co-expression with the chaperone team (KJE, ClpB, and ELS) resulted in a higher yield of active estUT1 in a soluble fraction of cell lysate (Figure 1, line 4). The specific activity of purified esterase in a soluble fraction after its co-expression with chaperones increased up to $200.7 \pm 15.5 \mathrm{U} \mathrm{mg}^{-1}$, as compared to esterase expressed without chaperones $\left(22.6 \pm 1.7 \mathrm{U} \mathrm{mg}^{-1}\right)$. These results correlate with the data on the expression of other lipolytic enzymes; for example, co-expression of the molecular chaperone team KJE and ELS with the lipase from Psychrobacter sp. resulted in an increase in its specific activity from $66.51 \pm 3.84$ to $108.77 \pm 4.62 \mathrm{U} \mathrm{mg}^{-1}$ in E. coli [20]. These results confirm that the expression of E. coli molecular chaperones (KJE, ClpB, and ELS) has a positive effect on the yield of the soluble esterase estUT1. The resulting highly active purified protein from E. coli co-expressing chaperones and estUT1 was further used to prepare CLEAs biocatalyst.

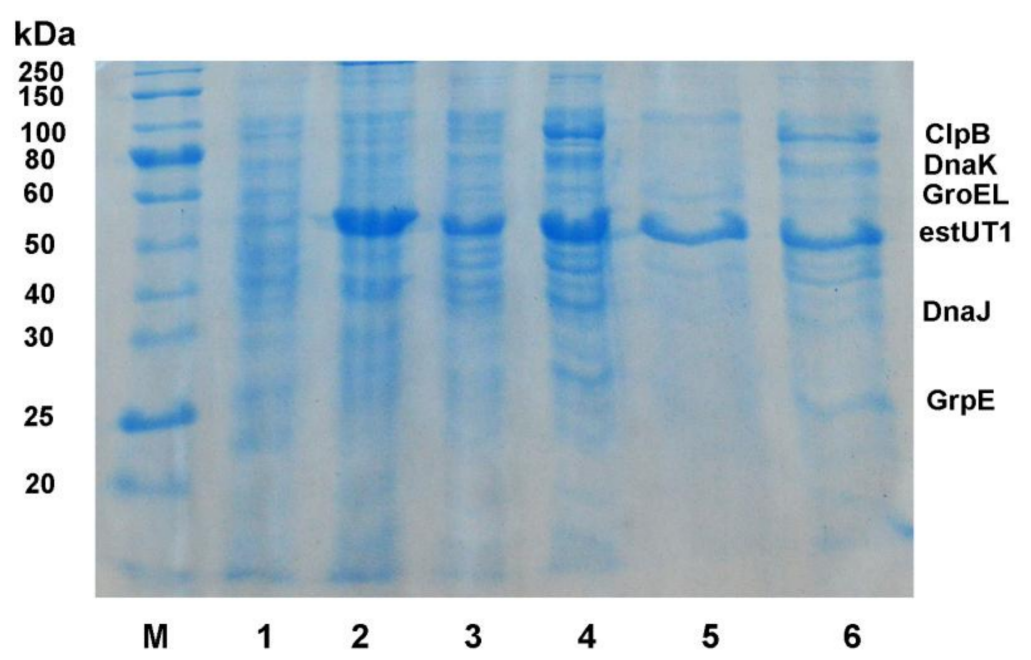

Figure 1. Co-expression of the molecular chaperone team (KJE, ClpB, and ELS) and the esterase estUT1 in E. coli BL21(DE3). M: protein molecular weight marker; 1: E. coli BL21(DE3) transformed with pET32b vector (soluble fraction); 2: E. coli BL21(DE3) transformed with pET32b-UT1 plasmid (insoluble fraction); 3: E. coli BL21(DE3) transformed with pET32b-UT1 plasmid (soluble fraction); 4: E. coli BL21(DE3) transformed with pET32b-UT1 co-expressed with chaperones (soluble fraction); 5: estUT1 (Ni-NTA purification); 6: estUT1 co-expressed with chaperones (Ni-NTA purification).

\subsection{Preparation of CLEA-estUT1}

In this study, the CLEAs approach was used for the preparation of biocatalyst from the esterase estUT1 for application in malathion hydrolysis. The procedure involves the aggregation of free enzyme from the aqueous solution with a precipitation agent (ammonium sulfate, ethanol, acetone), followed 
by cross-linking of aggregates by a bifunctional agent (glutaraldehyde) [36]. This approach does not require the use of a carrier [22], therefore resulting in an improvement of biocatalyst activity.

\subsubsection{Selection of Precipitant}

Various chemicals including acetone, tert-butanol, isopropanol, ethanol, and ammonium sulfate $(50 \%, w / v)$ were tested using the precipitant-protein ratio of 3:1 $(v / v)$ to select the optimal precipitant for the preparation of CLEAs from the purified esterase estUT1. Results are shown in Table 1.

Table 1. Effect of various precipitants on the activity of CLEAs biocatalyst.

\begin{tabular}{cc}
\hline Precipitant Type & Recovered Activity, \% \\
\hline Acetone & $30.3 \pm 2.8$ \\
tert-Butanol & $34.5 \pm 4.7$ \\
Isopropanol & $8.7 \pm 1.1$ \\
Ethanol & $6.2 \pm 0.4$ \\
Ammonium sulfate $(50 \%, w / v)$ & $58.4 \pm 4.1$ \\
\hline
\end{tabular}

Preparation of biocatalyst: $0.5 \mathrm{~mL}$ of the enzyme solution $\left(1 \mathrm{mg} \mathrm{mL}^{-1}\right)$, precipitant-protein ratio $3: 1(v / v), 75 \mathrm{mM}$ glutaraldehyde, $4 \mathrm{~h}$ of cross-linking.

Ammonium sulfate is a widely used precipitant for preparation of CLEAs from various enzymes including lipases [37], esterases [38], amylases [39], and proteases [40]. In this study, ammonium sulfate was also found as the most suitable precipitant and used for further studies on biocatalyst preparation.

\subsubsection{Selection of Additives}

In this study, two additives were tested in order to elucidate their effect on the activity of CLEAs (Table 2): bovine serum albumin (BSA) as a protein feeder [41] and SDS as a surfactant that facilitates the precipitation of aggregates in a stable conformation and increases the interfacial surface of the enzyme [42]. In this study, BSA increased the CLEAs activity up to $154.2 \pm 16.5 \%$. This may be due to the presence of free amino groups on the surface of the protein, for example, lysine, which reacts with glutaraldehyde, thereby preventing the denaturation of protein [43]. If SDS was used as an additive, CLEA-estUT1 showed only a slight increase in its activity (up to $109.7 \pm 8.4 \%$ ), which correlates with the data of Gupta et al. [42]. They reported an efficient cross-linking of the enzyme after precipitation with ammonium sulfate, along with an increase in the activity of CLEAs in the presence of SDS by two-fold. According to these data, BSA was selected as the most effective additive for CLEAs preparation.

Table 2. Effect of additives on the activity of CLEAs.

\begin{tabular}{cc}
\hline Additives & Relative Activity, \% \\
\hline Control $^{1}$ & $100.0 \pm 4.7$ \\
BSA & $154.2 \pm 16.5$ \\
SDS & $109.7 \pm 8.4$ \\
\hline
\end{tabular}

\footnotetext{
${ }^{1}$ Biocatalyst activity without additives was considered as $100 \%$ of the relative activity. Preparation of biocatalyst: $0.5 \mathrm{~mL}$ of the enzyme solution $\left(1 \mathrm{mg} \mathrm{mL}^{-1}\right), 60 \%(w / v)$ ammonium sulfate, $75 \mathrm{mM}$ glutaraldehyde, $4 \mathrm{~h}$ of cross-linking.
}

\subsubsection{Optimization of CLEA-estUT1 Preparation}

In this study, the RSM with FCCCD was used to optimize conditions for preparation of the CLEA-estUT1 biocatalyst (Table 3). The highest recovered CLEA-estUT1 activity was found to be $85.4 \%$ in run 7 , at $55 \%(w / v), 87.5 \mathrm{mM}$, and $0.2 \mathrm{mM}$ of ammonium sulfate, glutaraldehyde, and BSA, respectively, after $4.5 \mathrm{~h}$ of cross-linking. The coefficients of the equation of the complete regression model and their statistical significance were determined and evaluated after processing of 
the experimental data. A second-order polynomial model was built with the regression analysis and is represented by the following equation:

$$
\begin{gathered}
\text { Recovered activity of CLEA-estUT1 }(\%)=66.18+4.74 A+6.70 B+7.78 C+13.84 D+3.28 A B+ \\
2.12 A C+0.50 A D+0.45 B C+1.13 B D-0.47 C D-23.67 A^{2}-10.69 B^{2}-7.42 C^{2}+7.32 D^{2}
\end{gathered}
$$

where $A$ : cross-linking time, $B$ : concentration of ammonium sulfate, $C$ : concentration of glutaraldehyde, and $D$ : concentration of BSA.

Table 3. Experimental design for optimization of CLEA-estUT1 preparation.

\begin{tabular}{cccccc}
\hline Run & Time, $\mathbf{h}$ & Ammonium Sulfate, $\%(w / v)$ & Glutaraldehyde, $\mathbf{m M}$ & BSA, $\mathbf{m M}$ & Recovered Activity, $\%$ \\
\hline 1 & 4.5 & 55 & 25 & 0.105 & 45.1 \\
2 & 1 & 80 & 25 & 0.2 & 42.0 \\
3 & 8 & 30 & 25 & 0.01 & 7.5 \\
4 & 4.5 & 55 & 87.5 & 0.105 & 72.4 \\
5 & 1 & 80 & 25 & 0.01 & 9.7 \\
6 & 4.5 & 55 & 87.5 & 0.105 & 71.4 \\
7 & 4.5 & 55 & 87.5 & 0.2 & 85.4 \\
8 & 8 & 25 & 0.01 & 19.8 \\
9 & 1 & 80 & 150 & 0.01 & 21.8 \\
10 & 4.5 & 30 & 87.5 & 0.105 & 74.1 \\
11 & 1 & 55 & 150 & 0.2 & 38.7 \\
12 & 1 & 30 & 150 & 0.2 & 50.4 \\
13 & 4.5 & 80 & 87.5 & 0.105 & 65.1 \\
14 & 8 & 55 & 25 & 0.105 & 40.4 \\
15 & 1 & 55 & 150 & 0.2 & 29.6 \\
16 & 1 & 30 & 87.5 & 0.01 & 18.9 \\
17 & 4.5 & 80 & 87.5 & 0.105 & 43.2 \\
18 & 4.5 & 30 & 150 & 0.105 & 60.3 \\
19 & 8 & 80 & 150 & 0.01 & 18.2 \\
20 & 8 & 30 & 25 & 0.01 & 47.2 \\
21 & 1 & 80 & 87.5 & 0.01 & 5.3 \\
22 & 4.5 & 30 & 25 & 0.105 & 65.7 \\
23 & 8 & 50.5 & 0.2 & 32.1 \\
24 & 1 & 55 & 87.5 & 0.105 & 37.2 \\
25 & 4.5 & 30 & 150 & 0.01 & 54.2 \\
26 & 8 & 55 & 87.5 & 0.2 & 52.4 \\
27 & 4.5 & 55 & 25 & 0.105 & 70.6 \\
28 & 8 & 30 & 150 & 0.2 & 51.3 \\
29 & 8 & 55 & 150 & 0.2 & 70.0 \\
30 & 4.5 & 80 & 0.105 & 65.0 \\
\hline
\end{tabular}

Table 4 shows the result of analysis of variance (ANOVA), which verifies the significance of the model as well as the effect of individual independent variables and their interaction on the response. The efficiency of the resulting model was indicated by the high value of $R^{2}(0.97)$ and adjusted $R^{2}(0.94)$, and the model equation accounts for 97 or $94 \%$ variation. The $F$-value $(33.36)$ and $p$-value $(<0.0001)$ of this model confirm that the model is significant. The $p$-values presented in Table 4 show that the most significant factors in the CLEA-estUT1 preparation are the concentrations of BSA and glutaraldehyde $(p<0.0001)$. The time of cross-linking $(0.0021)$ and the concentration of ammonium sulfate $(0.0001)$ have a less pronounced effect on CLEA-estUT1 activity. 
Table 4. ANOVA for CLEA-estUT1 preparation.

\begin{tabular}{cccc}
\hline Source & Sum of Squares & $\boldsymbol{F}$-Value & $\boldsymbol{p}$-Value \\
\hline Model & $13,771.01$ & 33.36 & $<0.0001$ \\
Time, A & 403.56 & 13.69 & 0.0021 \\
Ammonium sulfate, B & 808.96 & 27.44 & 0.0001 \\
Glutaraldehyde, C & 1090.45 & 36.98 & $<0.0001$ \\
BSA, D & 3449.76 & 117.00 & $<0.0001$ \\
AB & 172.27 & 5.84 & 0.0288 \\
AC & 71.83 & 2.44 & 0.1394 \\
AD & 4.00 & 0.14 & 0.7178 \\
BC & 3.28 & 0.11 & 0.7435 \\
BD & 20.48 & 0.69 & 0.4177 \\
CD & 3.59 & 0.12 & 0.7319 \\
A $^{2}$ & 1451.57 & 49.23 & $<0.0001$ \\
B $^{2}$ & 296.06 & 10.04 & 0.0064 \\
C $^{2}$ & 142.83 & 4.84 & 0.0438 \\
D $^{2}$ & 138.84 & 4.71 & 0.0465 \\
Lack of fit & 375.04 & 2.79 & 0.1345 \\
\hline
\end{tabular}

The three-dimensional (3D) response surface (Figure 2) represents the regression equation used for the analysis of the interaction between variables and determination of the optimum concentration of each factor for maximizing biocatalyst activity. The 3D plot shows the concentration functions of two variables at a fixed value at the central point of the remaining factors.

The time of cross-linking is an important parameter for CLEAs preparation, and for different enzymes, may vary from $1 \mathrm{~h} \mathrm{[44]} \mathrm{to} 20 \mathrm{~h} \mathrm{[23].} \mathrm{In} \mathrm{this} \mathrm{study,} \mathrm{this} \mathrm{parameter} \mathrm{was} 1-8 \mathrm{~h}$. Figure $2 \mathrm{a}-\mathrm{c}$ shows the effect of cross-linking time on the activity of CLEAs, depending on the concentration of ammonium sulfate, glutaraldehyde, and BSA, respectively. The highest activity of CLEAs was observed at $4.5-5.5 \mathrm{~h}$.

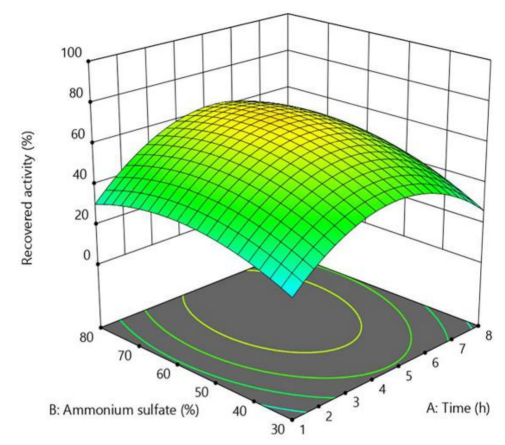

(a)

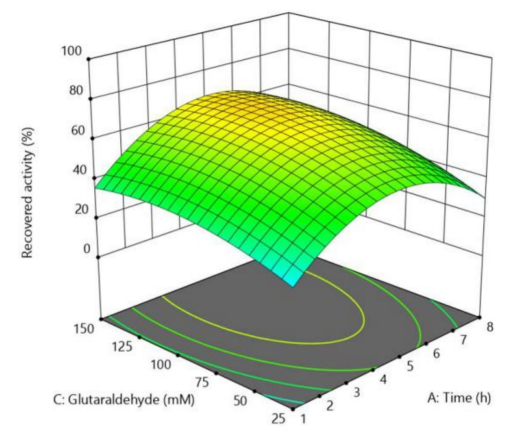

(b)

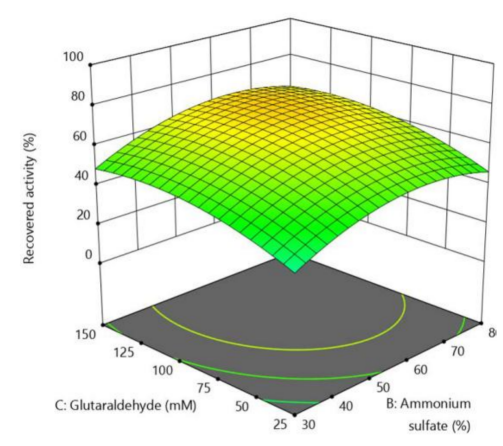

(d)

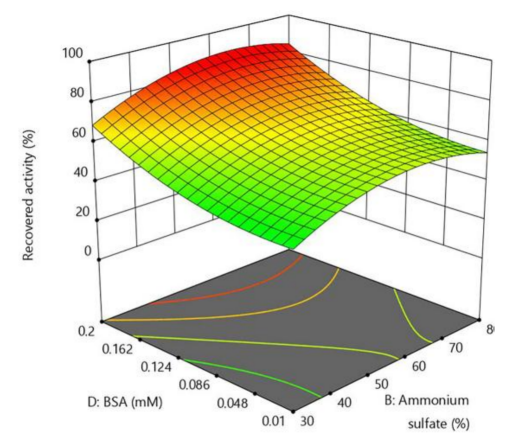

(e)

Figure 2. Cont. 


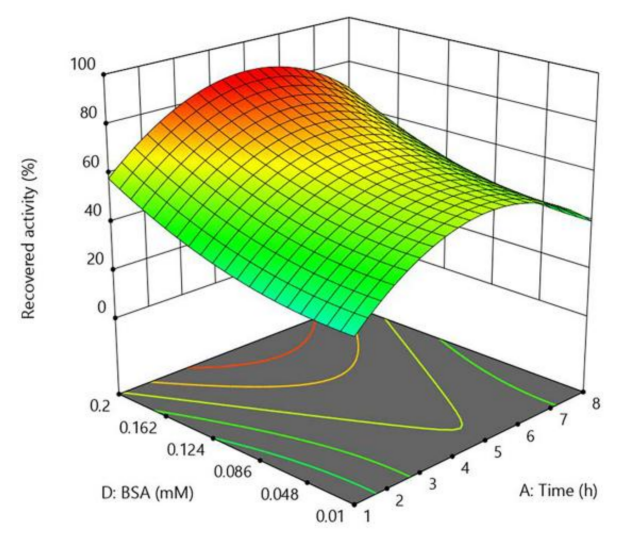

(c)

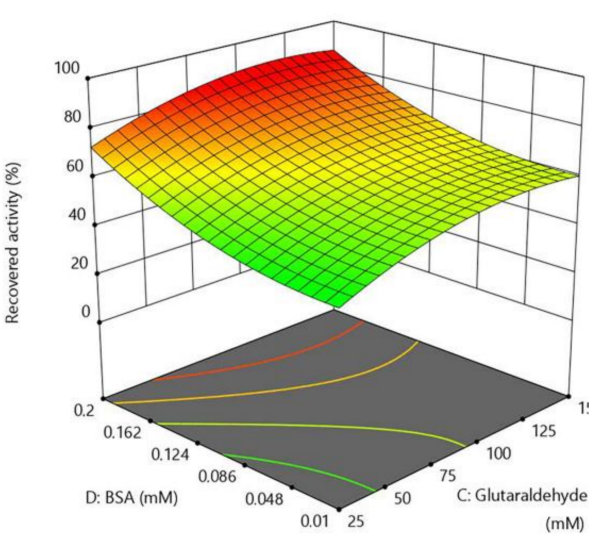

(f)

Figure 2. Response surface plots representing the dependence of the CLEA-estUT1 activity on the parameters of biocatalyst preparation: (a) concentration of ammonium sulfate and cross-linking time; (b) concentration of glutaraldehyde and cross-linking time; (c) concentration of BSA and cross-linking time; (d) concentration of glutaraldehyde and ammonium sulfate; (e) concentration of BSA and ammonium sulfate; (f) concentration of BSA and glutaraldehyde.

The amount of precipitant (ammonium sulfate) plays an important role in CLEAs preparation, thereby affecting the size of the protein aggregates. It was found that a low concentration of precipitant results in its inability to form protein aggregates. On the contrary, a high precipitant concentration can inhibit the enzyme activity [37]. According to the model from this study, the protein is preferably precipitated from the solution at $60-70 \%$ saturation with ammonium sulfate (Figure $2 \mathrm{a}, \mathrm{d}, \mathrm{e}$ ). This range of concentrations is widely used for the precipitation of enzymes. For example, CLEAs of lipase M37 from Photobacterium lipolyticum [23] and $\alpha$-amylase from Bacillus amyloliquefaciens [45] were prepared with $70 \%$ saturated ammonium sulfate.

The concentration of glutaraldehyde strongly affects the activity of the enzyme. If a low concentration of a cross-linker is used, the enzyme molecule may remain flexible and unstable, which will lead to protein leaching in solution. Excessive use of glutaraldehyde can cause loss of the minimum flexibility of the enzyme due to the formation of protein aggregates with a strong diffusion resistance [41]. Therefore, the concentration of glutaraldehyde should be optimized in order to obtain active CLEAs. As shown in Figure $2 \mathrm{~b}, \mathrm{~d}, \mathrm{f}$, the highest activity of CLEAs was observed when 115-125 mM of glutaraldehyde was used for biocatalyst preparation. Previously, 75 and $60 \mathrm{mM}$ glutaraldehyde was applied for the preparation of CLEAs of lipase from Rhizopus oryzae [44] and esterase from Bacillus subtilis [38], respectively. However, higher concentrations of the cross-linking agent have also been used for CLEAs preparation. For example, $140 \mathrm{mM}$ glutaraldehyde has been used to immobilize catalase from the bovine liver [24].

In this study, the effect of the BSA concentration on the activity of CLEAs was evaluated. Figure 2c,e,f shows that its effect on the activity of CLEAs depends on the time of cross-linking and concentrations of ammonium sulfate and glutaraldehyde, respectively. The highest recovered activity of CLEA-estUT1 was at $0.2 \mathrm{mM} \mathrm{BSA}$, which correlates with the study of Khanahmadi et al. [37], where $0.17 \mathrm{mM}$ BSA was used as a co-feeder for the preparation of CLEAs of lipase isolated from cocoa pods.

The model obtained in this study was validated as shown in Table 5, and the experimental values were compared with those predicted by the model. Thus, the model based on RSM with FCCCD showed a high correlation with the experimental data and can be used for modeling of the CLEA-estUT1 preparation. The optimal conditions for the preparation of CLEAs biocatalyst from the esterase estUT1 were $65.1 \%$ ammonium sulfate, $120.6 \mathrm{mM}$ glutaraldehyde, and $0.2 \mathrm{mM}$ BSA at $5.1 \mathrm{~h}$ of cross-linking. 
Table 5. Validation of the experimental model.

\begin{tabular}{cccccc}
\hline \multirow{2}{*}{ Time, h } & \multirow{2}{*}{ Ammonium Sulfate, \% (w/v) } & Glutaraldehyde, mM & BSA, mM & \multicolumn{2}{c}{ Recovered Activity, \% } \\
\cline { 5 - 6 } & 65.1 & 120.6 & 0.2 & $90.6 \pm 2.7$ & 91.3 \\
\hline
\end{tabular}

\subsection{Study of CLEA-estUT1 Properties}

Biocatalysts for industrial applications including wastewater treatment must be stable in a broad range of conditions. Therefore, a comparative analysis of the stability of free and immobilized esterase estUT1 is performed here in order to evaluate the biocatalyst's effectiveness in the application of malathion hydrolysis in municipal wastewater.

\subsubsection{Effect of $\mathrm{pH}$ and Temperature on the Activity and Stability of Free estUT1 and CLEA-estUT1}

The catalytic activity of free and immobilized estUT1 esterase was evaluated at pH 5.0-10.0. As shown in Figure 3a, the optimum $\mathrm{pH}$ for both forms of enzyme was 8.0, but CLEA-estUT1 had higher activity at $\mathrm{pH} 7.0$ and 9.0, which was $92.4 \pm 7.6 \%$ and $90.3 \pm 4.7 \%$, respectively. The higher $\mathrm{pH}$ stability of CLEAs (Figure 3b) is due to the covalent cross-linking between enzyme aggregates that increases the rigidity of the enzyme structure [46].

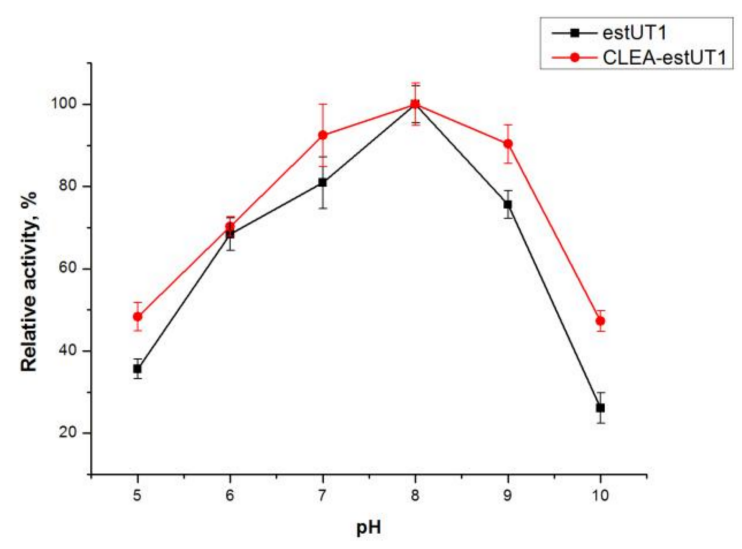

(a)

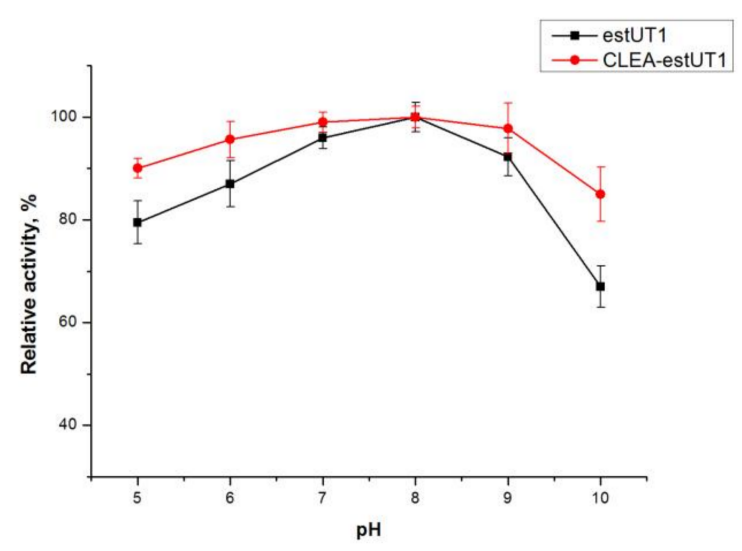

(b)

Figure 3. Effect of $\mathrm{pH}$ on the activity and stability of free and immobilized estUT1. (a) The activity of estUT1 and CLEA-estUT1 in buffers with different $\mathrm{pH}$ values was assayed with $p$-nitrophenyl acetate $\left(p\right.$ NPC2) as a substrate at $50^{\circ} \mathrm{C}$. (b) The pH stability of estUT1 and CLEA-estUT1 was examined in different buffers at $50^{\circ} \mathrm{C}$ after $1 \mathrm{~h}$ of incubation. 
As shown in Figure 4, enzyme immobilization does not affect the temperature optimum of estUT1 esterase $\left(80^{\circ} \mathrm{C}\right)$. However, CLEA-estUT1 has higher activity at all temperatures. Higher temperature tolerance of the immobilized enzyme is due to the decrease of the conformational flexibility of the protein.

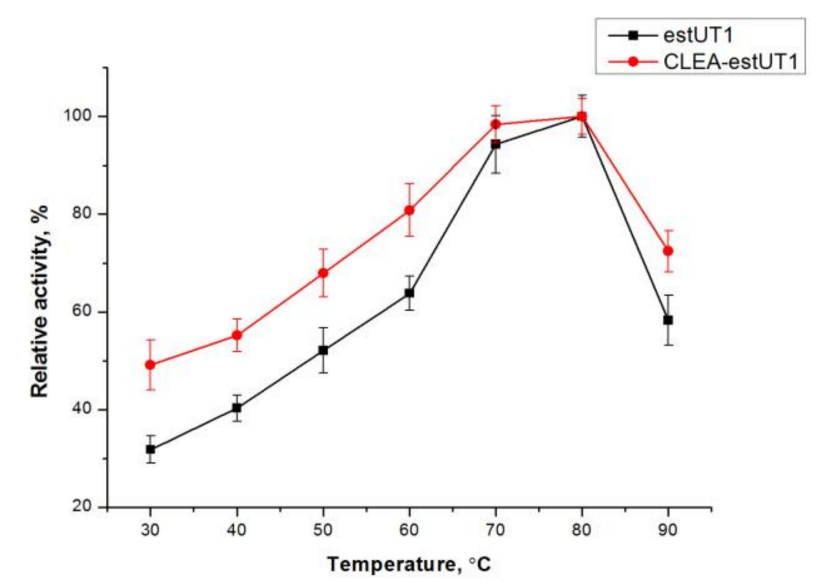

Figure 4. Effect of temperature on the activity of free and immobilized estUT1. The activity of estUT1 and CLEA-estUT1 at temperature range of $30-90^{\circ} \mathrm{C}$ was assayed in $50 \mathrm{mM}$ of Tris- $\mathrm{HCl}$ buffer (pH 8.0) using $p$ NPC2 as a substrate.

Comparative study of the thermostability of free and immobilized enzyme was performed at $50-80^{\circ} \mathrm{C}$ for $1-8 \mathrm{~h}$ (Figure 5). The inactivation rate constants $\left(k_{\mathrm{i}}\right)$ and the half-life $\left(t_{1 / 2}\right)$ values of free and immobilized enzyme were determined according to Equations (3) and (4), respectively (Table 6). The $k_{\mathrm{i}}$ and $t_{1 / 2}$ values suggest that the thermostability of the esterase is considerably enhanced after immobilization. In fact, the $t_{1 / 2}$ of free estUT1 increased 1.9- and 1.5-fold after CLEAs preparation at 50 and $60^{\circ} \mathrm{C}$, respectively. The higher thermostability of the immobilized enzymes is due to additional covalent bonding in the tertiary and secondary structure that prevents their denaturation at the high temperatures $[37,40,46]$.

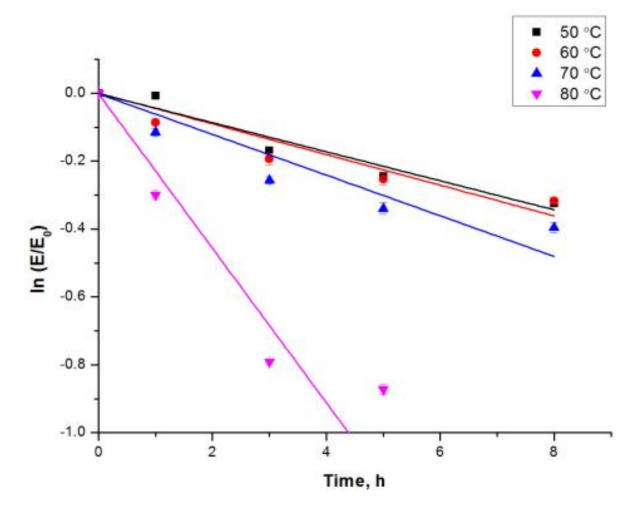

(a)

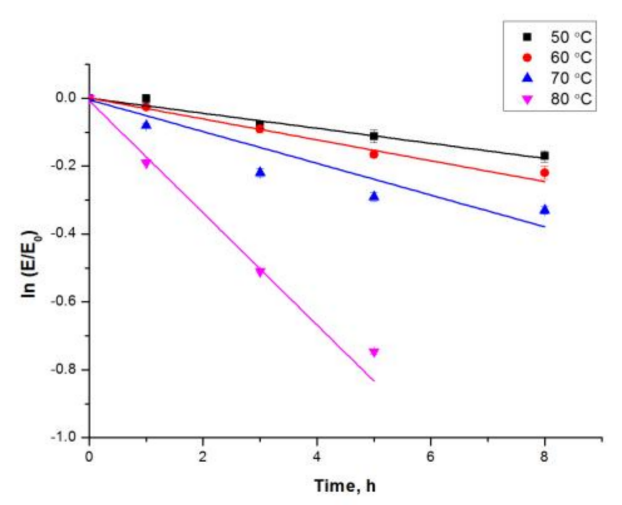

(b)

Figure 5. Thermal inactivation of free (a) and immobilized (b) estUT1 at 50-80 ${ }^{\circ} \mathrm{C}$. The thermostability of estUT1 and CLEA-estUT1 was assayed by incubating the enzyme in $50 \mathrm{mM}$ of Tris- $\mathrm{HCl}$ buffer ( $\mathrm{pH} 8.0$ ) at $50-80{ }^{\circ} \mathrm{C}$ for $1-8 \mathrm{~h}$. 
Table 6. Comparison of the inactivation constants $\left(k_{\mathrm{i}}\right)$ and half-life $\left(t_{1 / 2}\right)$ values of free estUT1 and CLEA-estUT1 at $50-80{ }^{\circ} \mathrm{C}$.

\begin{tabular}{ccccc}
\hline \multirow{2}{*}{ Temperature, ${ }^{\circ} \mathbf{C}$} & \multicolumn{2}{c}{$k_{\mathrm{i}, \mathbf{h}^{-\mathbf{1}}} \boldsymbol{t}_{\mathbf{1 / 2}}, \mathbf{h}$} \\
\cline { 2 - 5 } & estUT1 & CLEA-estUT1 & estUT1 & CLEA-estUT1 \\
\hline 50 & $4.3 \times 10^{-2}$ & $2.2 \times 10^{-2}$ & 16.1 & 31.3 \\
60 & $4.5 \times 10^{-2}$ & $3.1 \times 10^{-2}$ & 15.4 & 22.5 \\
70 & $6.0 \times 10^{-2}$ & $4.7 \times 10^{-2}$ & 11.5 & 14.8 \\
80 & $22.7 \times 10^{-2}$ & $16.5 \times 10^{-2}$ & 3.1 & 4.2 \\
\hline
\end{tabular}

\subsubsection{Effect of Chemicals on the Activity of Free estUT1 and CLEA-estUT1}

The effects of various chemicals on the activity of free and immobilized estUT1 were observed after $1 \mathrm{~h}$ of incubation at $50{ }^{\circ} \mathrm{C}$ (Figure 6). The immobilized enzyme showed higher tolerance against these reagents than the enzyme in free form, which is consistent with the data of $[26,47]$. The activity of immobilized esterase as compared to free enzyme after incubation with $10 \mathrm{mM}$ PMSF, dithiothreitol (DTT), $\beta$-mercaptoethanol (BME), 1\% SDS, and Tween 20 was increased by 1.9, 1.2, 1.2, 1.5 , and 1.6 times, respectively. Therefore, the immobilization of estUT1 by the cross-linking method can effectively protect the enzyme from thermal inactivation and increase tolerance to chemicals including water pollutants (surfactants, detergents [48], heavy metals, organic contaminants [49], etc.).

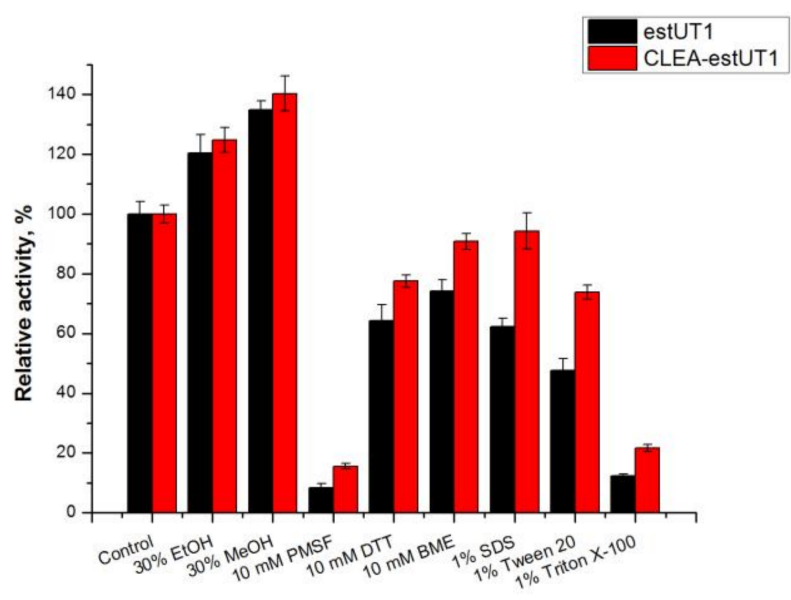

Figure 6. Effect of various chemicals on the activity of free and immobilized estUT1. EstUT1 and CLEA-estUT1 were incubated with different chemicals in $50 \mathrm{mM}$ of Tris- $\mathrm{HCl}$ buffer $(\mathrm{pH} 8.0)$ at $50{ }^{\circ} \mathrm{C}$ for $1 \mathrm{~h}$.

\subsubsection{Kinetic Studies of Free and Immobilized estUT1}

Kinetic parameters of the free estUT1 and CLEA-estUT1 were assayed with commonly used substrates including $p$ NPC2, $p$-nitrophenyl butyrate ( $p$ NPC4), $p$-nitrophenyl octanoate ( $p$ NPC8), and malathion in order to study the effect of immobilization on the catalytic efficiency of the esterase estUT1. The results are summarized in Table 7. Free estUT1 is more selective towards short-chain fatty acids $(\mathrm{C} 2>\mathrm{C} 4>\mathrm{C} 8)$, revealing the smallest $K_{\mathrm{m}}$ value for $p \mathrm{NPC} 2$ among the $p$-nitrophenyl esters examined. After enzyme immobilization, the $K_{\mathrm{m}}$ value of CLEA-estUT1 becomes higher than that of free esterase for all substrates, including $p$-nitrophenyl esters and malathion. This effect might be due to the changes in protein structure during cross-linking that results in a reduced accessibility of the substrate to the active site of the enzyme [41,50]. The higher $K_{\mathrm{m}}$ for immobilized enzyme as compared to free enzyme was also observed for CLEAs of protease [51], lipase [37], and esterase [38]. The catalytic efficiency $\left(k_{\mathrm{cat}} / K_{\mathrm{m}}\right)$ of CLEA-estUT1 was lower as compared to free enzyme, which correlates with other studies $[37,38]$. The kinetic studies revealed a high catalytic efficiency of the enzyme toward 
malathion. The $k_{\text {cat }} / K_{\mathrm{m}}$ value for estUT1 $\left(835.5 \pm 58.7 \mathrm{~s}^{-1} \mathrm{mM}^{-1}\right)$ was higher than that of other known hydrolytic enzymes. For example, the $k_{\text {cat }} / K_{\mathrm{m}}$ value for the organophosphorus hydrolase mutant from Flavobacterium spp. was $154.91 \mathrm{~s}^{-1} \mathrm{mM}^{-1}$ [10], and for a hydrolase from Aspergillus niger ZD11 was $55 \mathrm{~s}^{-1} \mathrm{mM}^{-1}$ [52].

Thus, the CLEA-estUT1 biocatalyst, which is stable to various inhibitory conditions $(\mathrm{pH}$, temperature, different chemicals) and shows a high catalytic efficiency against malathion, can be used as an effective biocatalyst in the reaction of malathion hydrolysis.

Table 7. Comparison of kinetic parameters of free estUT1 and CLEA-estUT1.

\begin{tabular}{ccccccc}
\hline \multirow{2}{*}{ Substrate } & \multicolumn{2}{c}{$\boldsymbol{K}_{\mathbf{m}, \boldsymbol{\mu M}}$} & \multicolumn{2}{c}{$\boldsymbol{k}_{\text {cat }} \mathbf{s}^{-\mathbf{1}}$} & \multicolumn{2}{c}{$\boldsymbol{k}_{\text {cat }} / \boldsymbol{K}_{\mathbf{m}}, \mathbf{s}^{-\mathbf{1}} \mathbf{~ m M}^{-\mathbf{1}}$} \\
\cline { 2 - 7 } & estUT1 & CLEA-estUT1 & estUT1 & CLEA-estUT1 & estUT1 & CLEA-estUT1 \\
\hline$p$ NPC2 & $96.0 \pm 5.3$ & $176.7 \pm 8.5$ & $27.0 \pm 0.7$ & $31.1 \pm 1.2$ & $281.3 \pm 8.7$ & $176.1 \pm 2.2$ \\
$p$ NPC4 & $550.0 \pm 78.1$ & $710.7 \pm 64.7$ & $39.2 \pm 1.2$ & $41.8 \pm 0.4$ & $72.1 \pm 8.8$ & $59.1 \pm 5.6$ \\
$p$ NPC8 & $2113.3 \pm 180.4$ & $2490.0 \pm 141.8$ & $54.1 \pm 2.0$ & $56.9 \pm 1.2$ & $25.2 \pm 1.3$ & $22.9 \pm 1.1$ \\
Malathion & $19.5 \pm 1.1$ & $29.6 \pm 3.3$ & $16.3 \pm 0.3$ & $15.2 \pm 1.0$ & $835.5 \pm 58.7$ & $515.4 \pm 22.8$ \\
\hline
\end{tabular}

\subsubsection{Malathion Hydrolysis with CLEA-estUT1}

The stability of a biocatalyst during operation is an important criterion for its industrial application. The reusability of CLEA-estUT1 biocatalyst produced in optimal conditions (Table 5) was studied in the reaction of malathion hydrolysis at its concentration of $27.5 \mathrm{mg} \mathrm{L}^{-1}$ at $37^{\circ} \mathrm{C}$ in different media (Figure 7): buffer comprising $50 \mathrm{mM}$ Tris- $\mathrm{HCl}$ ( $\mathrm{pH} 7.0$ ), synthetic wastewater medium according to Organization of Economic Co-operation and Development (OECD), and autoclaved real municipal wastewater (MWW). In all studied media, a high percentage of malathion removal was observed: after the first cycle, the percent of malathion degradation was $99.4 \pm 2.8 \%, 99.2 \pm 2.4 \%$, and $99.5 \pm 1.4 \%$ in $50 \mathrm{mM}$ Tris- $\mathrm{HCl}$ (pH 7.0), OECD, and MWW, respectively. During the operation, the activity of the biocatalyst decreased gradually during all cycles of malathion hydrolysis. However, the catalyst showed high stability in all studied media, providing a percent of malathion degradation above $55 \%$ after 25 cycles of reaction $(350 \mathrm{~h})$.

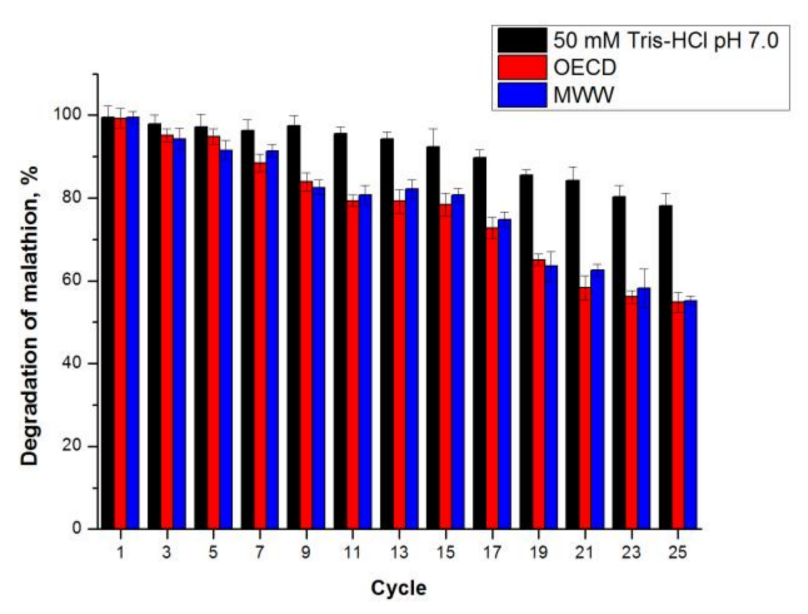

Figure 7. Operational stability of CLEA-estUT1 during cycles of malathion hydrolysis in various media. Reactions were performed at initial malathion concentration of $27.5 \mathrm{mg} \mathrm{L}^{-1}$ at $37^{\circ} \mathrm{C}$. After each cycle, biocatalyst was centrifuged and washed three times with $50 \mathrm{mM}$ Tris- $\mathrm{HCl}(\mathrm{pH} 7.0)$, and then resuspended in a fresh reaction mixture. OECD: synthetic wastewater; MWW: autoclaved real municipal wastewater. 


\subsubsection{Comparison of Microbial Biodegradation and CLEA-estUT1 Hydrolysis of Malathion}

Typically, the microbial biodegradation of malathion (up to 50-80\%) takes from a few hours up to a few days (Table 8) if the liquid culture is used. For example, B. licheniformis strain ML-1 provided about $78 \%$ malathion removal from liquid media within five days [8]. Carboxylesterase D1CarE5 from the bacterium Alicyclobacillus tengchongensis, which was cloned in pET28a (+) and expressed in E. coli BL21(DE3), revealed the high capability to hydrolyze malathion: the removal of malathion was $89 \%$ within $100 \mathrm{~min}$ at its initial concentration of $5 \mathrm{mg} \mathrm{L}^{-1}$ [11]. However, such a high activity of the carboxylesterase D1CarE5 may be due to a low initial concentration of malathion in the solution. Bacillus sp. S14 immobilized in 3\% calcium alginate is the only biocatalyst that has been applied in malathion removal from aqueous solutions (64.4\% under optimal conditions) [15]. The CLEA-estUT1 biocatalyst in this study not only exceeds the activity of the last microbial biocatalyst (Table 8) [15], but also remains stable (malathion removal $>78.1 \pm 3.1 \%$ ) within 25 cycles of hydrolysis in $50 \mathrm{mM}$ Tris- $\mathrm{HCl}$ ( $\mathrm{pH} 7.0)$. In this study, the real municipal wastewater (MWW) supplemented with malathion was successfully used for the evaluation of the ability of CLEA-estUT1 to hydrolyse insecticide. Under these conditions, the percentage of malathion removal was above $55.2 \pm 1.1 \%$ for 25 cycles. Application of immobilized esterase estUT1 allowed the effective hydrolysis of malathion and repeated use of the biocatalyst, which make it promising for application in processes of insecticide biodegradation, including wastewater treatment.

Table 8. Comparison of malathion biodegradation with microbial biocatalysts.

\begin{tabular}{|c|c|c|c|}
\hline Biocatalyst & Experimental Condition & Removal of Malathion, \% & Reference \\
\hline CLEA-estUT1 (U. thermosphaericus) & $\begin{array}{c}\text { Malathion concentration }=27.5 \mathrm{mg} \mathrm{L}^{-1} \\
\text { Temperature }=37^{\circ} \mathrm{C} \\
\text { Time }=14 \mathrm{~h} \\
\mathrm{pH}=7.0 \\
\mathrm{rpm}=250\end{array}$ & $99.4 \pm 2.8$ & This study \\
\hline CLEA-estUT1 (U. thermosphaericus) & $\begin{array}{c}\text { Malathion concentration }=27.5 \mathrm{mg} \mathrm{L}^{-1} \\
\text { Temperature }=37^{\circ} \mathrm{C} \\
\text { Time }=14 \mathrm{~h} \\
\text { Municipal wastewater (MWW) } \\
\text { rpm }=250\end{array}$ & $99.5 \pm 1.4$ & This study \\
\hline $\begin{array}{c}\text { Bacillus sp. S14 immobilized in } \\
3 \% \text { calcium alginate }\end{array}$ & $\begin{array}{c}\text { Malathion concentration }=50 \mathrm{mg} \mathrm{L}^{-1} \\
\text { Temperature }=25^{\circ} \mathrm{C} \\
\text { Time }=8 \mathrm{~h} \\
\mathrm{pH}=7.0 \\
\mathrm{rpm}=120\end{array}$ & 64.4 & [15] \\
\hline B. licheniformis strain ML-1 & $\begin{array}{c}\text { Malathion concentration }=25 \mathrm{mg} \mathrm{L}^{-1} \\
\text { Temperature }=32{ }^{\circ} \mathrm{C} \\
\text { Time }=5 \text { days } \\
\mathrm{pH}=7.5 \\
\mathrm{rpm}=250\end{array}$ & 78 & [8] \\
\hline $\begin{array}{l}\text { Carboxylesterase D1CarE5 } \\
\text { (A. tengchongensis) }\end{array}$ & $\begin{array}{c}\text { Malathion concentration }=5 \mathrm{mg} \mathrm{L}^{-1} \\
\text { Temperature }=37^{\circ} \mathrm{C} \\
\text { Time }=100 \mathrm{~min} \\
\mathrm{pH}=7.0\end{array}$ & 89 & [11] \\
\hline Bacillus thuringiensis & $\begin{array}{c}\text { Malathion concentration }=250 \mathrm{mg} \mathrm{L}^{-1} \\
\text { Temperature }=30{ }^{\circ} \mathrm{C} \\
\text { Time }=3 \text { days }\end{array}$ & 50 & [53] \\
\hline Bacillus cereus strain PU & $\begin{array}{c}\text { Malathion concentration }=72.5 \mathrm{mg} \mathrm{L}^{-1} \\
\text { Temperature }=30^{\circ} \mathrm{C} \\
\text { Time }=7 \text { days } \\
\mathrm{pH}=7.0\end{array}$ & 49.31 & [54] \\
\hline P. putida & $\begin{array}{c}\text { Malathion concentration }=125 \mathrm{mg} \mathrm{L}^{-1} \\
\text { Temperature }=30^{\circ} \mathrm{C} \\
\text { Time }=7 \text { days } \\
\mathrm{pH}=7.0 \\
\mathrm{rpm}=150\end{array}$ & 72 & [5] \\
\hline
\end{tabular}




\section{Materials and Methods}

\subsection{Materials}

Plasmid pET32b-UT1 containing the esterase gene estUT1 (Genbank accession number MF156209) was constructed in our laboratory [30]; E. coli strain BL21(DE3) (Thermo Fisher Scientific, Waltham, MA, USA) was used for the enzyme expression; plasmids pBB540 and pBB542 were a gift from Bernd Bukau (Addgene plasmids \#27393 and \#27395, respectively, Cambridge, MA, USA) [35]; $p$-nitrophenyl esters and SDS were purchased from Sigma-Aldrich (St. Louis, MO, USA). All other chemicals were of analytical grade (Merck, Darmstadt, Germany).

\subsection{Expression of Esterase estUT1}

Overnight culture of E. coli BL21(DE3) cells transformed with plasmid pET32b-UT1 was inoculated into $250 \mathrm{~mL}$ of $\mathrm{LB}$ and cultivated at $32{ }^{\circ} \mathrm{C}$ until $\mathrm{OD}_{600}$ of 0.6. Protein synthesis was induced with $0.5 \mathrm{mM}$ IPTG at $16^{\circ} \mathrm{C}$ for $20 \mathrm{~h}$. Cells were harvested by centrifugation $\left(3000 \times g, 4{ }^{\circ} \mathrm{C}\right.$ for $\left.10 \mathrm{~min}\right)$, washed twice by $50 \mathrm{mM}$ Tris- $\mathrm{HCl} \mathrm{pH} 7.0$, and disrupted by sonication ( 5 cycles, $40 \mathrm{~s}$ pulse, $20 \mathrm{~s}$ pause) at $0{ }^{\circ} \mathrm{C}$. The cell-free protein extract was prepared by centrifugation at $5500 \times g$ and $4{ }^{\circ} \mathrm{C}$ for $20 \mathrm{~min}$. The supernatant and the precipitate were collected as soluble and insoluble fractions, respectively. The supernatant containing the recombinant esterase was purified by ion metal affinity chromatography using a Ni-NTA (Ni-nitrilotriacetic acid) agarose; the enzyme was eluted using an increasing concentration gradient of imidazole $(0-300 \mathrm{mM})$ in $50 \mathrm{mM}$ Tris- $\mathrm{HCl} \mathrm{pH} 8.0,0.5 \mathrm{M} \mathrm{NaCl}$.

\subsection{Co-Expression of Chaperones}

For co-expression of esterase with chaperones, E. coli BL21(DE3) cells were first transformed with plasmids pBB540 (GrpE, ClpB) and pBB542 (DnaK, DnaJ, GroEL, and GroES) [35]. Then, the chaperone-overexpressing cells were transformed with plasmid pET32b-UT1. EstUT1 was expressed as described above, and after cell lysis, the supernatant was collected as a soluble fraction. This fraction was purified with Ni-NTA agarose as described above.

The molecular mass of proteins was examined with $12 \%$ sodium dodecyl sulfate-polyacrylamide gel electrophoresis (SDS-PAGE) according to the standard procedures [55]. Protein concentration was determined by the Bradford method [56] with bovine serum albumin as a standard.

\subsection{Enzyme Activity Assay}

Esterase activity was determined by measuring the amount of $p$-nitrophenol released after hydrolysis of $p$ NPC2 [57]. The $p$ NPC2 was dissolved in acetonitrile at a concentration of $100 \mathrm{mM}$. Ethanol and $50 \mathrm{mM}$ Tris- $\mathrm{HCl}(\mathrm{pH}$ 8.0) buffer were subsequently added to this solution, in which the final ratio of acetonitrile to ethanol to Tris- $\mathrm{HCl}$ buffer was 1:4:95 $(v / v / v)$. The reaction was initiated by adding $20 \mu \mathrm{L}$ of the enzyme solution $\left(0.05 \mathrm{mg} \mathrm{mL}^{-1}\right)$ to $150 \mu \mathrm{L}$ of substrate mixture and incubated for $15 \mathrm{~min}$ at $50^{\circ} \mathrm{C}$, followed by analysis of absorbance at $405 \mathrm{~nm}$. One unit (U) of esterase activity was defined as the amount of enzyme that released $1 \mu \mathrm{mol}$ of $p$-nitrophenol per minute.

Recovered activity of CLEA-estUT1 biocatalyst was calculated by the following equation [58]:

$$
\begin{gathered}
\text { Recovered activity }(\%)=(\text { total activity of CLEAs }) /(\text { total activity of free enzyme for } \\
\text { CLEAs preparation }) \times 100
\end{gathered}
$$

Malathion hydrolysis was assayed according to the method of Liang et al. [52], with minor modifications. $5 \mu \mathrm{L}$ of malathion solution in ethanol $(10 \mathrm{mM})$ was added to $515 \mu \mathrm{L}$ of $50 \mathrm{mM}$ Tris- $\mathrm{HCl} \mathrm{pH} 7.0$ and $80 \mu \mathrm{L}$ of enzyme $\left(0.05 \mathrm{mg} \mathrm{mL}^{-1}\right)$ for incubation at $37^{\circ} \mathrm{C}$ and $250 \mathrm{rpm}$ for $30 \mathrm{~min}$. Residual malathion was extracted with $n$-hexane and analyzed by gas chromatography mass spectrometry (GC/MS). GC/MS quantitative analysis was performed by using an Agilent 7000B GC/MS (Agilent Technologies, Santa Clara, CA, USA) system equipped with a HP-5ms fused silica 
capillary column $(30 \mathrm{~m} \times 0.25 \mathrm{~mm} \times 0.25 \mu \mathrm{m})$. Temperature was programmed from $200{ }^{\circ} \mathrm{C}(3 \mathrm{~min})$ to $250^{\circ} \mathrm{C}$ at $5{ }^{\circ} \mathrm{C} \mathrm{min}^{-1}$. Helium was used as a carrier gas $\left(1.2 \mathrm{~mL} \mathrm{~min}^{-1}\right)$ and injector temperature was $250^{\circ} \mathrm{C}$. The mass spectrometer was operated in electron ionization (EI) mode at $70 \mathrm{eV}$; selected ion monitoring (SIM) mode with $m / z 125$ (the major fragment of malathion parent ion $(\mathrm{m} / z 330)$ after EI); $m / z 154$ (diphenyl as an internal standard). Malathion amount was calculated as malathion/diphenyl peak ratio. Malathion solution without enzyme was used as a control.

\subsection{Preparation of CLEA-estUT1}

Preparation of CLEAs from the estUT1 after its co-expression with the chaperone team of KJE, $\mathrm{ClpB}$, and ELS was performed as follows: $0.5 \mathrm{~mL}$ of the enzyme solution $\left(1 \mathrm{mg} \mathrm{mL}^{-1}\right.$ in $50 \mathrm{mM}$ Tris-HCl $\mathrm{pH}$ 8.0) was mixed with the varying concentrations of precipitant, water solution of glutaraldehyde, and additives to the final volume of $2 \mathrm{~mL}$. The solution was agitated at $200 \mathrm{rpm}$ and $4{ }^{\circ} \mathrm{C}$ for a required period. Samples were collected and centrifuged at $4000 \times \mathrm{g}$ and $4{ }^{\circ} \mathrm{C}$ for $15 \mathrm{~min}$, then washed two times with $50 \mathrm{mM}$ Tris- $\mathrm{HCl} \mathrm{pH}$ 8.0. The biocatalyst was stored in $50 \mathrm{mM}$ Tris- $\mathrm{HCl} \mathrm{pH} 8.0$ at $4{ }^{\circ} \mathrm{C}$.

\subsection{Selection of Precipitant}

The effect of different precipitants including acetone, tert-butanol, isopropanol, ethanol, and ammonium sulfate $50 \%(w / v)$ was assayed in this study. The precipitant-enzyme ratio was 2:1 $(v / v)$. Biocatalyst was prepared as described in Section 3.5. $75 \mathrm{mM}$ glutaraldehyde was used as cross-linker; time of cross-linking was $4 \mathrm{~h}$.

\subsection{Selection of Various Additives}

BSA (10 mg) and SDS (10 mg) as additives were used in this study. Biocatalyst was prepared as described in Section 3.5. The concentrations of ammonium sulfate and glutaraldehyde were $60 \%(w / v)$ and $75 \mathrm{mM}$, respectively. The cross-linking time was $4 \mathrm{~h}$.

\subsection{Optimization of CLEA-estUT1 Preparation}

The process for preparation of CLEA-estUT1 biocatalyst was optimized with RSM based on FCCCD. Four factors were selected: cross-linking time $(1,4.5$, and $8 \mathrm{~h})$, concentration of ammonium sulfate $(30,55$, and $80 \%, w / v)$, glutaraldehyde $(25,87.5$, and $150 \mathrm{mM})$ and BSA $(0.01,0.105$, and $0.2 \mathrm{mM})$. The design consisted of 30 runs with six replicates at the central point and provided enough information to establish a second-order polynomial model for the response surface. Regression analysis and regression equation (ANOVA) was performed using Design-Expert software v. 10 (Stat-Ease Inc., Minneapolis, MN, USA).

\subsection{Properties of CLEA-estUT1 Biocatalyst}

\subsubsection{Effect of $\mathrm{pH}$ and Temperature}

The effect of $\mathrm{pH}$ was examined by assaying enzyme activity of free and immobilized estUT1 at $\mathrm{pH}$ 5.0-10.0 in different $50 \mathrm{mM}$ buffers: citrate phosphate ( $\mathrm{pH}$ 5.0-6.0), sodium phosphate ( $\mathrm{pH}$ 6.0-8.0), Tris- $\mathrm{HCl}$ (pH 8.0-9.0), and glycine- $\mathrm{NaOH}$ (pH 9.0-10.0). Reactions were performed using $p \mathrm{NPC} 2$ as a substrate in buffer at $50^{\circ} \mathrm{C}$. The $\mathrm{pH}$ stability of estUT1 and CLEA-estUT1 was examined in different buffers at $50{ }^{\circ} \mathrm{C}$ after $1 \mathrm{~h}$ of incubation.

The temperature optimum of free and immobilized estUT1 was determined in the range of $30-90{ }^{\circ} \mathrm{C}$ in $50 \mathrm{mM}$ of Tris- $\mathrm{HCl}$ buffer ( $\mathrm{pH}$ 8.0) with $p \mathrm{NPC} 2$ as a substrate. The thermostability of estUT1 and CLEA-estUT1 was examined by incubating the enzyme in $50 \mathrm{mM}$ of Tris-HCl buffer $(\mathrm{pH} 8.0)$ at $50-80^{\circ} \mathrm{C}$ for $1-8 \mathrm{~h}$. The inactivation rate constant $\left(k_{\mathrm{i}}\right)$ was determined from the slope of the inactivation time using equation [59]:

$$
\ln \left(E / E_{0}\right)=-k_{\mathrm{i}} t
$$


where $E$ : the residual enzyme activity after heat treatment for time $t$ and $E_{0}$ : the initial activity before the heat treatment.

The half-life of thermal inactivation $\left(t_{1 / 2}\right)$ was determined according to equation [60]:

$$
t_{1 / 2}=\ln (2) / k_{\mathrm{i}}
$$

\subsubsection{Effect of Chemicals}

The effect of various reagents (30\% ethanol and methanol, $v / v ; 10 \mathrm{mM} \mathrm{PMSF,} \mathrm{BME,} \mathrm{and} \mathrm{DTT;}$ $1 \%$ SDS, Tween 20, and Triton X-100, $w / v$ ) on the activity of free and immobilized estUT1 was determined by adding these chemicals to the enzyme or biocatalyst solution and assayed after preincubation for $1 \mathrm{~h}$ at $50{ }^{\circ} \mathrm{C}$. Esterase activity without addition of reagents was defined as $100 \%$.

\subsubsection{Kinetic Parameters}

Kinetic parameters $\left(K_{\mathrm{m}}, k_{\mathrm{cat}}\right)$ of free and immobilized estUT1 were determined by nonlinear regression using the Michaelis-Menten equation. The kinetic assay was performed with different concentrations $(0.003-10 \mathrm{mM})$ of $p \mathrm{NPC} 2, p \mathrm{NPC} 4, p \mathrm{NPC} 8$, and malathion as substrates with the standard procedure as described above (Section 3.4).

\subsubsection{Operational Stability of CLEA-estUT1 during Hydrolysis of Malathion}

The operational stability of CLEA-estUT1 was determined by repeated use of CLEA-estUT1 in hydrolysis of malathion in three different media: autoclaved wastewater after the primary settler from the Novosibirsk municipal wastewater treatment facility (MWW), autoclaved synthetic wastewater (OECD) [61], and $50 \mathrm{mM}$ Tris-HCl pH 7.0. 0.1 g CLEA-estUT1 in $495.8 \mu \mathrm{L}$ of the medium was incubated with $4.2 \mu \mathrm{L}$ malathion solution in $\mathrm{EtOH}(10 \mathrm{mM})$ at $37^{\circ} \mathrm{C}$ at $250 \mathrm{rpm}$ for $14 \mathrm{~h}$. Residual malathion was determined as described in Section 3.4. Between cycles, CLEAs were recovered by centrifugation $\left(4000 \times \mathrm{g}, 4^{\circ} \mathrm{C}, 5 \mathrm{~min}\right)$ and washed three times with $50 \mathrm{mM}$ Tris- $\mathrm{HCl} \mathrm{pH} \mathrm{7.0.}$

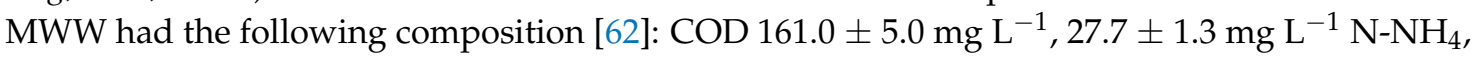
$0.2 \pm 0.0 \mathrm{mg} \mathrm{L}^{-1} \mathrm{~N}_{-N O}, 1.8 \pm 0.1 \mathrm{mg} \mathrm{L}^{-1} \mathrm{P}_{3} \mathrm{PO}_{4}, 10.7 \pm 1.0 \mathrm{mg} \mathrm{L}^{-1} \mathrm{~S}_{-} \mathrm{SO}_{4}$, and $139.0 \pm 5.0 \mathrm{mg} \mathrm{L}^{-1} \mathrm{Cl}$.

\subsection{Statistical Analysis}

Data on the experiments of the central compositional plan (RSM with FCCCD) were used to determine the regression coefficients of the quadratic polynomial model and the F-test analysis. Dispersion analysis (ANOVA), regression analysis, and surface plotting were used to optimize the CLEAs preparation. The accuracy of the resulting polynomial model was estimated using the determination coefficient $R^{2}$. All experiments in this work, with the exception of the FCCCD experiments, were performed in triplicate, and the results are presented as the arithmetic mean \pm standard deviation.

\section{Conclusions}

In this study, the CLEAs biocatalyst was used for the first time for the hydrolysis of malathion in municipal wastewater. A complex approach involving the improved expression of a new thermostable esterase estUT1 in a soluble form and optimization of CLEAs preparation was applied to maximize biocatalyst activity. In particular, the intracellular aggregation of the esterase estUT1 from $U$. thermosphaericus in E. coli BL21(DE3) was partially resolved by its co-expression with molecular chaperones (KJE, ClpB, and ELS), and a stable CLEA-estUT1 biocatalyst was prepared after purification of estUT1 from the soluble fraction of cell protein. Optimization of the CLEAs preparation was performed with RSM using FCCCD. Immobilization by the cross-linking method allowed the stability of the esterase estUT1 at high temperatures $\left(50-80^{\circ} \mathrm{C}\right)$ to be increased, in a wide range of $\mathrm{pH}(5.0-10.0)$. Immobilization improved enzyme tolerance against various chemicals, especially PMSF, DTT, BME, $1 \%$ SDS, and Tween 20. CLEA-estUT1 showed high activity in the reaction of malathion hydrolysis 
in wastewater (the removal of malathion was $99.5 \pm 1.4 \%$ ) and reusability, maintaining $55.2 \pm 1.1 \%$ of its activity after 25 cycles of malathion hydrolysis at $37^{\circ} \mathrm{C}$. A novel CLEA-estUT1 biocatalyst can be effectively applied for the removal of malathion from wastewaters from municipal wastewater treatment facilities and in clean-out procedures of malathion storage tanks.

Acknowledgments: The reported study was funded by Russian Foundation for Basic Research according to the research project no. 18-38-00386.

Author Contributions: Yuliya V. Samoylova, Ksenia N. Sorokina, and Valentin N. Parmon designed the experiments; Yuliya V. Samoylova and Alexander V. Piligaev performed the experiments; Yuliya V. Samoylova, Alexander V. Piligaev, and Ksenia N. Sorokina analyzed the data; Yuliya V. Samoylova and Ksenia N. Sorokina wrote the paper.

Conflicts of Interest: The authors declare no conflict of interest.

\section{References}

1. Firestone, J.A.; Smith-Weller, T.; Franklin, G.; Swanson, P.; Longstreth, W.T., Jr.; Checkoway, H. Pesticides and risk of parkinson disease: A population-based case-control study. Arch. Neurol. 2005, 62, 91-95. [CrossRef] [PubMed]

2. Alavanja, M.C.R.; Hoppin, J.A.; Kamel, F. Health effects of chronic pesticide exposure: Cancer and neurotoxicity. Ann. Rev. Public Health 2004, 25, 155-197. [CrossRef] [PubMed]

3. Zhang, Y.; Pagilla, K. Treatment of malathion pesticide wastewater with nanofiltration and photo-fenton oxidation. Desalination 2010, 263, 36-44. [CrossRef]

4. Shayeghi, M.; Dehghani, M.H.; Alimohammadi, M.; Goodini, K. Using ultraviolet irradiation for removal of malathion pesticide in water. J. Arthropod-Borne Dis. 2012, 6, 45-53. [PubMed]

5. Geed, S.R.; Kureel, M.K.; Shukla, A.K.; Singh, R.S.; Rai, B.N. Biodegradation of malathion and evaluation of kinetic parameters using three bacterial species. Resour. Effic. Technol. 2016, 2, S3-S11. [CrossRef]

6. Kim, Y.-H.; Ahn, J.-Y.; Moon, S.-H.; Lee, J. Biodegradation and detoxification of organophosphate insecticide, malathion by Fusarium oxysporum f. sp. pisi cutinase. Chemosphere 2005, 60, 1349-1355. [CrossRef] [PubMed]

7. Ibrahim, W.M.; Karam, M.A.; El-Shahat, R.M.; Adway, A.A. Biodegradation and utilization of organophosphorus pesticide malathion by cyanobacteria. BioMed Res. Int. 2014, 2014, 392682. [CrossRef] [PubMed]

8. Khan, S.; Zaffar, H.; Irshad, U.; Ahmad, R.; Khan, A.R.; Shah, M.M.; Bilal, M.; Iqbal, M.; Naqvi, T. Biodegradation of malathion by Bacillus licheniformis strain ML-1. Arch. Biol. Sci. 2016, 68, 9. [CrossRef]

9. Goda, S.K.; Elsayed, I.E.; Khodair, T.A.; El-Sayed, W.; Mohamed, M.E. Screening for and isolation and identification of malathion-degrading bacteria: Cloning and sequencing a gene that potentially encodes the malathion-degrading enzyme, carboxylestrase in soil bacteria. Biodegradation 2010, 21, 903-913. [CrossRef] [PubMed]

10. Schofield, D.A.; DiNovo, A.A. Generation of a mutagenized organophosphorus hydrolase for the biodegradation of the organophosphate pesticides malathion and demeton-s. J. Appl. Microbiol. 2010, 109, 548-557. [CrossRef] [PubMed]

11. Xie, Z.; Xu, B.; Ding, J.; Liu, L.; Zhang, X.; Li, J.; Huang, Z. Heterologous expression and characterization of a malathion-hydrolyzing carboxylesterase from a thermophilic bacterium, Alicyclobacillus tengchongensis. Biotechnol. Lett. 2013, 35, 1283-1289. [CrossRef] [PubMed]

12. Sheldon, R.A.; van Pelt, S. Enzyme immobilisation in biocatalysis: Why, what and how. Chem. Soc. Rev. 2013, 42, 6223-6235. [CrossRef] [PubMed]

13. Samoylova, Y.V.; Piligaev, A.V.; Sorokina, K.N.; Rozanov, A.S.; Peltek, S.E.; Novikov, A.A.; Almyasheva, N.R.; Parmon, V.N. Application of the immobilized bacterial recombinant lipase from Geobacillus stearothermophilus G3 for the production of fatty acid methyl esters. Catal. Ind. 2016, 8, 187-193. [CrossRef]

14. Samoylova, Y.V.; Piligaev, A.V.; Sorokina, K.N.; Parmon, V.N. Enzymatic interesterification of sunflower oil and hydrogenated soybean oil with the immobilized bacterial recombinant lipase from Geobacillus stearothermophilus G3. Catal. Ind. 2017, 9, 62-70. [CrossRef]

15. Adhikari, S.; Chattopadhyay, P.; Ray, L. Biosorption of malathion by immobilized cells of Bacillus sp. S14. Chem. Spec. Bioavailabil. 2010, 22, 271-276. [CrossRef] 
16. Saida, F.; Uzan, M.; Odaert, B.; Bontems, F. Expression of highly toxic genes in E. coli: Special strategies and genetic tools. Curr. Protein Pept. Sci. 2006, 7, 47-56. [CrossRef] [PubMed]

17. De Marco, A. Strategies for successful recombinant expression of disulfide bond-dependent proteins in Escherichia coli. Microb. Cell Fact. 2009, 8, 26. [CrossRef] [PubMed]

18. Rosano, G.L.; Ceccarelli, E.A. Recombinant protein expression in Escherichia coli: Advances and challenges. Front. Microbiol. 2014, 5, 172. [CrossRef] [PubMed]

19. Valero, F. Heterologous expression systems for lipases: A review. In Lipases and Phospholipases: Methods and Protocols; Sandoval, G., Ed.; Humana Press: Totowa, NJ, USA, 2012; pp. 161-178.

20. Shuo-shuo, C.; Xue-zheng, L.; Ji-hong, S. Effects of co-expression of molecular chaperones on heterologous soluble expression of the cold-active lipase lip-948. Protein Expr. Purif. 2011, 77, 166-172. [CrossRef] [PubMed]

21. Singh, R.K.; Tiwari, M.K.; Singh, R.; Lee, J.-K. From protein engineering to immobilization: Promising strategies for the upgrade of industrial enzymes. Int. J. Mol. Sci. 2013, 14, 1232-1277. [CrossRef] [PubMed]

22. Mohamad, N.R.; Marzuki, N.H.C.; Buang, N.A.; Huyop, F.; Wahab, R.A. An overview of technologies for immobilization of enzymes and surface analysis techniques for immobilized enzymes. Biotechnol. Biotechnol. Equip. 2015, 29, 205-220. [CrossRef] [PubMed]

23. Han, J.Y.; Kim, H. Transesterification using the cross-linked enzyme aggregate of Photobacterium lipolyticum lipase M37. J. Microbiol. Biotechnol. 2011, 21, 1159-1165. [CrossRef] [PubMed]

24. Tükel, S.S.; Hürrem, F.; Yildirim, D.; Alptekin, Ö. Preparation of crosslinked enzyme aggregates (CLEA) of catalase and its characterization. J. Mol. Catal. B Enzym. 2013, 97, 252-257. [CrossRef]

25. Morales, A.; Barbosa, O.; Rueda, N.; Fonseca, Z.; Torres, R.; Rodrigues, R.C.; Ortiz, C.; Fernandez-Lafuente, R. Optimization and characterization of CLEAs of the very thermostable dimeric peroxidase from Roystonea regia. RSC Adv. 2015, 5, 53047-53053. [CrossRef]

26. Jang, E.; Ryu, B.; Kim, T. Identification, characterization, and immobilization of an organic solvent-stable alkaline hydrolase (PA27) from Pseudomonas aeruginosa MH38. Molecules 2014, 19, 14396. [CrossRef] [PubMed]

27. Kumari, V.; Shah, S.; Gupta, M.N. Preparation of biodiesel by lipase-catalyzed transesterification of high free fatty acid containing oil from Madhuca indica. Energy Fuels 2007, 21, 368-372. [CrossRef]

28. Piligaev, A.V.; Sorokina, K.N.; Samoylova, Y.V.; Parmon, V.N. Lipid production by microalga Micractinium sp. IC-76 in a flat panel photobioreactor and its transesterification with cross-linked enzyme aggregates of Burkholderia cepacia lipase. Energy Convers. Manag. 2018, 156, 1-9. [CrossRef]

29. Shah, S.; Gupta, M.N. Kinetic resolution of ( \pm )-1-phenylethanol in [Bmim][PF6] using high activity preparations of lipases. Bioorgan. Med. Chem. Lett. 2007, 17, 921-924. [CrossRef] [PubMed]

30. Samoylova, Y.V.; Sorokina, K.N.; Romanenko, M.V.; Parmon, V.N. Cloning, expression and characterization of the esterase estUT1 from Ureibacillus thermosphaericus which belongs to a new lipase family XVIII. Extremophiles 2018, 22, 271-285. [CrossRef] [PubMed]

31. Mogk, A.; Mayer, M.P.; Deuerling, E. Mechanisms of Protein Folding: Molecular Chaperones and Their Application in Biotechnology. Chembiochem 2002, 3, 807-814. [CrossRef]

32. Schlieker, C.; Bukau, B.; Mogk, A. Prevention and reversion of protein aggregation by molecular chaperones in the E. coli cytosol: Implications for their applicability in biotechnology. J. Biotechnol. 2002, 96, 13-21. [CrossRef]

33. Mogk, A.; Tomoyasu, T.; Goloubinoff, P.; Rüdiger, S.; Röder, D.; Langen, H.; Bukau, B. Identification of thermolabile Escherichia coli proteins: Prevention and reversion of aggregation by DnaK and ClpB. EMBO J. 1999, 18, 6934-6949. [CrossRef] [PubMed]

34. Sørensen, H.P.; Mortensen, K.K. Soluble expression of recombinant proteins in the cytoplasm of Escherichia coli. Microb. Cell Fact. 2005, 4, 1. [CrossRef] [PubMed]

35. De Marco, A.; Deuerling, E.; Mogk, A.; Tomoyasu, T.; Bukau, B. Chaperone-based procedure to increase yields of soluble recombinant proteins produced in E. coli. BMC Biotechnol. 2007, 7, 32. [CrossRef] [PubMed]

36. Hanefeld, U.; Gardossi, L.; Magner, E. Understanding enzyme immobilisation. Chem. Soc. Rev. 2009, 38, 453-468. [CrossRef] [PubMed]

37. Khanahmadi, S.; Yusof, F.; Amid, A.; Mahmod, S.S.; Mahat, M.K. Optimized preparation and characterization of CLEA-lipase from cocoa pod husk. J. Biotechnol. 2015, 202, 153-161. [CrossRef] [PubMed] 
38. Zheng, G.-W.; Yu, H.-L.; Li, C.-X.; Pan, J.; Xu, J.-H. Immobilization of Bacillus subtilis esterase by simple cross-linking for enzymatic resolution of dl-menthyl acetate. J. Mol. Catal. B Enzym. 2011, 70, 138-143. [CrossRef]

39. Nadar, S.S.; Muley, A.B.; Ladole, M.R.; Joshi, P.U. Macromolecular cross-linked enzyme aggregates (M-CLEAs) of $\alpha$-amylase. Int. J. Biol. Macromol. 2016, 84, 69-78. [CrossRef] [PubMed]

40. Mahmod, S.S.; Yusof, F.; Jami, M.S.; Khanahmadi, S.; Shah, H. Development of an immobilized biocatalyst with lipase and protease activities as a multipurpose cross-linked enzyme aggregate (multi-CLEA). Process Biochem. 2015, 50, 2144-2157. [CrossRef]

41. Dong, T.; Zhao, L.; Huang, Y.; Tan, X. Preparation of cross-linked aggregates of aminoacylase from Aspergillus melleus by using bovine serum albumin as an inert additive. Bioresour. Technol. 2010, 101, 6569-6571. [CrossRef] [PubMed]

42. Gupta, R.; Beg, Q.; Lorenz, P. Bacterial alkaline proteases: Molecular approaches and industrial applications. Appl. Microbiol. Biotechnol. 2002, 59, 15-32. [PubMed]

43. Torres, M.P.G.; Foresti, M.L.; Ferreira, M.L. Effect of different parameters on the hydrolytic activity of cross-linked enzyme aggregates (CLEAs) of lipase from Thermomyces lanuginosa. Biochem. Eng. J. 2013, 72, 18-23. [CrossRef]

44. Kartal, F.; Kilinc, A. Crosslinked aggregates of Rhizopus oryzae lipase as industrial biocatalysts: Preparation, optimization, characterization, and application for enantioselective resolution reactions. Biotechnol. Prog. 2012, 28, 937-945. [CrossRef] [PubMed]

45. Talekar, S.; Waingade, S.; Gaikwad, V.; Patil, S.; Nagavekar, N. Preparation and characterization of cross linked enzyme aggregates (CLEAs) of Bacillus amyloliquefaciens alpha amylase. J. Biochem. Technol. 2012, 3, 349-353.

46. Yu, C.-Y.; Li, X.-F.; Lou, W.-Y.; Zong, M.-H. Cross-linked enzyme aggregates of mung bean epoxide hydrolases: A highly active, stable and recyclable biocatalyst for asymmetric hydrolysis of epoxides. J. Biotechnol. 2013, 166, 12-19. [CrossRef] [PubMed]

47. Ju, H.; Ryu, B.H.; Doohun Kim, T. Identification, characterization, immobilization of a novel type hydrolase (LmH) from Listeria monocytogenes. Int. J. Biol. Macromol. 2015, 72, 63-70. [CrossRef] [PubMed]

48. Scott, M.J.; Jones, M.N. The biodegradation of surfactants in the environment. Biochim. Biophys. Acta (BBA) Biomembr. 2000, 1508, 235-251. [CrossRef]

49. Amin, M.T.; Alazba, A.A.; Manzoor, U. A review of removal of pollutants from water/wastewater using different types of nanomaterials. Adv. Mater. Sci. Eng. 2014, 2014, 825910. [CrossRef]

50. Xu, D.-Y.; Yang, Y.; Yang, Z. Activity and stability of cross-linked tyrosinase aggregates in aqueous and nonaqueous media. J. Biotechnol. 2011, 152, 30-36. [CrossRef] [PubMed]

51. Mahmod, S.S.; Yusof, F.; Jami, M.S.; Khanahmadi, S. Optimizing the preparation conditions and characterization of a stable and recyclable cross-linked enzyme aggregate (CLEA)-protease. Bioresour. Bioprocess. 2016, 3, 3. [CrossRef]

52. Liang, W.Q.; Wang, Z.Y.; Li, H.; Wu, P.C.; Hu, J.M.; Luo, N.; Cao, L.X.; Liu, Y.H. Purification and characterization of a novel pyrethroid hydrolase from Aspergillus niger ZD11. J. Agric. Food Chem. 2005, 53, 7415-7420. [CrossRef] [PubMed]

53. Mohamed, Z.K.; Ahmed, M.A.; Fetyan, N.A.; Elnagdy, S.M. Isolation and molecular characterisation of malathion-degrading bacterial strains from waste water in Egypt. J. Adv. Res. 2010, 1, 145-149. [CrossRef]

54. Singh, B.; Kaur, J.; Singh, K. Biodegradation of malathion by Brevibacillus sp. strain KB2 and Bacillus cereus strain PU. World J. Microbiol. Biotechnol. 2012, 28, 1133-1141. [CrossRef] [PubMed]

55. Laemmli, U.K. Cleavage of structural proteins during the assembly of the head of bacteriophage T4. Nature 1970, 227, 680. [CrossRef] [PubMed]

56. Bradford, M.M. A rapid and sensitive method for the quantitation of microgram quantities of protein utilizing the principle of protein-dye binding. Anal. Biochem. 1976, 72, 248-254. [CrossRef]

57. Eom, G.T.; Song, J.K.; Ahn, J.H.; Seo, Y.S.; Rhee, J.S. Enhancement of the efficiency of secretion of heterologous lipase in Escherichia coli by directed evolution of the abc transporter system. Appl. Environ. Microbiol. 2005, 71, 3468-3474. [CrossRef] [PubMed]

58. Kim, M.H.; Park, S.; Kim, Y.H.; Won, K.; Lee, S.H. Immobilization of formate dehydrogenase from Candida boidinii through cross-linked enzyme aggregates. J. Mol. Catal. B Enzym. 2013, 97, 209-214. [CrossRef] 
59. Lawton, J.M.; Doonan, S. Thermal inactivation and chaperonin-mediated renaturation of mitochondrial aspartate aminotransferase. Biochem. J. 1998, 334, 219. [CrossRef] [PubMed]

60. Xu, Z.; Liu, S.; Lu, X.; Rao, S.; Kang, Z.; Li, J.; Wang, M.; Chen, J. Thermal inactivation of a recombinant lipoxygenase from Pseudomonas aeruginosa BBE in the absence and presence of additives. J. Sci. Food Agric. 2014, 94, 1753-1757. [CrossRef] [PubMed]

61. OECD. Guidelines for Testing of Chemicals Simulation Tests-Aerobic Sewage Treatment; Technical Report; Organisation for Economic Co-Operation and Development (OECD): Paris, France, 1996; pp. 19-142.

62. Piligaev, A.V.; Sorokina, K.N.; Shashkov, M.V.; Parmon, V.N. Screening and comparative metabolic profiling of high lipid content microalgae strains for application in wastewater treatment. Bioresour. Technol. 2018, 250, 538-547. [CrossRef] [PubMed]

C 2018 by the authors. Licensee MDPI, Basel, Switzerland. This article is an open access article distributed under the terms and conditions of the Creative Commons Attribution (CC BY) license (http:/ / creativecommons.org/licenses/by/4.0/). 